\title{
Morphology of the Liver of European Bison
}

\author{
Stanisław PYTEL \& Mieczysław WĘGRZYN
}

Pytel S. \& Węgrzyn M., 1976: Morphology of the liver of European bison. Acta theriol. 21, 2: 19-30 [With 5 Tables \& 4 Figs].

The investigations were carried out on the livers of 47 bisons $\left(32 \sigma^{x}+15 q\right)$ in the age from 1 day to 24 years. The measurements and morphological observations were based on fixed material, while the weight data - on fresh material. The liver of European bison resembles that of the cattle. It shows brown-red colour, moderately pronounced lobular structure and distinct separation into the lobes: right, left, quadrate and caudate. In relationship to the degree of development of lobes (mainly the left one) the liver of adult bisons may be either triangle-shaped $(56 \%$ of cases), rectangular $(12 \%)$ and intermediate $(32 \%)$. Bison's liver differs from that of the cattle by a more pronounced development of the right lobe and lesser development of the left lobe. The absolute liver weight in adult bisons amounts to $8.21 \mathrm{~kg}\left(9.01 \mathrm{~kg}\right.$ in $\sigma^{7}, 5.80 \mathrm{~kg}$ in $\left.\mathrm{O}\right)$, and the relative weight to $1.17 \%$ $\left(1.24 \%\right.$ in $\sigma^{\top}, 1.09 \%$ in $\left.q\right)$.

[Inst. Anim. Physiol., Agric. Acad., 03-849 Warszawa, Grochowska 272]

\section{INTRODUCTION}

In the available literature only a few brief reports were found on the liver morphology of the European bison ( $\mathrm{O}$ wen, 1848; M üller, 1852), some of them being limited to the comparison of the weight of this organ (Sztolcman, 1926). The study of Zarzycki (1957) gives a description of the microscopic structure of bison's liver. These reports are based on single cases and sometimes contain contradictory data. In the present study macroscopic structure of bison's liver was investigated utilizing a large number of samples.

\section{MATERIAL AND METHOD}

Material deriving from the carcasses of 47 European bisons ( 32 males and 15 females) was used in the investigations. The material was divided into 4 age groups: newborns (including fullterm foetus), calves, young bisons and adult individuals. The observations were carried out mostly on the material fixed by the method of intraarterial injections (Pilarski et al., 1967). The measurements were based on the principles employed for the cattle liver (E i chel, 1925) and 
utilized fixed material, wrie the data on the weight of the organ concerned fresh material. The capacity of the gall bladder was determined by the method used for measuring the volume of stomach and intestine of the bison (Pyte l, 1969).

\section{RESULTS}

\section{Macroscopic Structure of the Liver}

The liver of adult bisons is characterized by variability of shapes: it may rescmble a triangle, rectangle, or intermediate forms between these two figures.

Liver showing the shape of a triangle (Fig. 1) occurred the most often in the examined material $(56 \%$ cases). It is characterized by a poorly cieveloped left lobe, with normal right lobe. Margo obtusus constitutes

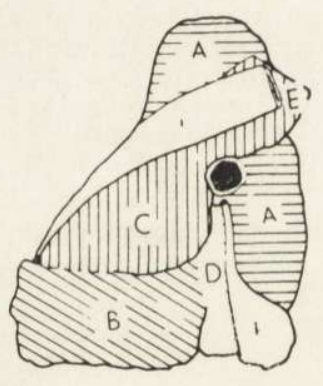

1.

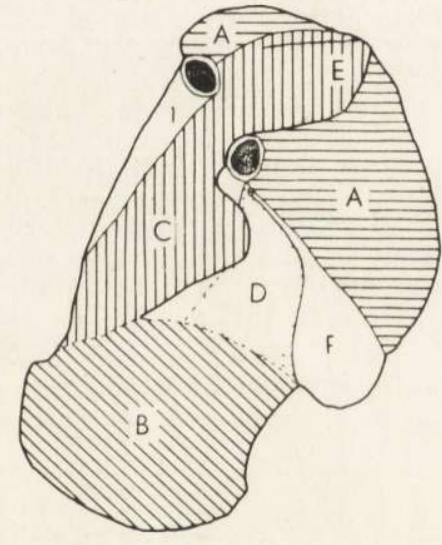

2.

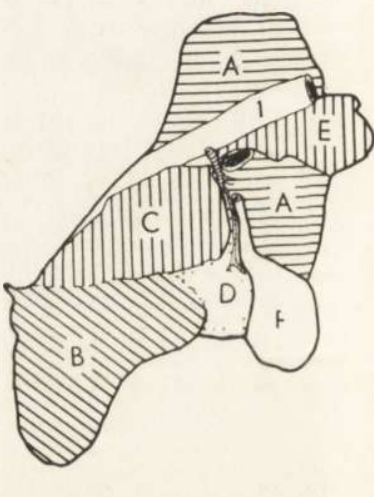

3.

Figs. 1-3. Division into lobes of differently shaped livers. 1. Triangular liver. 2. Rectengular liver. 3. Liver of the intermediate shape between triangle and rectangle.

in this form the base of the triangle, the apex of which is on margo acutus in the vicinity of the gall bladder separating the right border from the ventral border.

I iver of the rectangle shape was found rarely ( $12 \%$ of cases). It shows a slight predominance of the right lobe. The ventral border of the liver is always convex (Fig. 2).

Liver of the intermediate shape (32\% of cases among adult bisons) has a rather well developend right lobe in comparison with the left one, margo acutus of the latter being concave (Fig. 3). 
Liver parenchiyma visible through the peritoneum and fibrous capsules is brown-red in colour. Five- or six-sided lateral hepatic lobules consisting of moderately developed connective tissue reach the diameter up to $1 \mathrm{~mm}$.

The division of the bison's liver into lobes is poorly marked. Independently of liver shape the left lobe is thinner and more narrow than the right one (Table 1). The visceral surface shows omasal and reticular impressions (rectangle liver), or only reticular impression and the semilunar notch on the ventral border instead of omasal impression - in the remaining types of liver. The quadrate lobe has the shape resembling triangle in most cases, and only rarely resembling rectangle. The umbilical fissure is well visible in adult bisons on both surfaces of the liver; its depth reaches 3.5 to $9.5 \mathrm{~cm}$. The right lobe surpasses the remaining lobes in respect of length and width; its dorsal surface shown broad and deep renal impression, limited to a considerable extent also by the caudate process. The caudate lobe is the thickest one in the bison (Table 1). Its papillary process is rounded or apical, turned in the side of the gall bladder or umbilical fissure. This process covers the medial part of porta of the liver and overlaps by 1 to $3 \mathrm{~cm}$ the quadrate lobe. The caudate process is prism-shaped and situated on the border of upper and intermediate one third part of the right lobe; the axis of the process runs in the dorsal-upper direction. The free end of the caudate process in most cases does not reach the liver border, or just ends at this point. Porta of the liver is relatively broad and its length ranges from 11.5 to $13.5 \mathrm{~cm}$ in females, and up to $17 \mathrm{~cm}$ in males.

\section{Position and Attachment of the Liver}

The bison's liver is situated almost totally in the right hypochondriac region, and only a small part of the left lobe, below the esophageal impression deviates by $2-4 \mathrm{~cm}$ to the left from the median sagittal plane. The right lobe is situated dorsally and caudally in respect of the left lobe in such a manner that margo obtusus lies medially and constitutes the left border, while margo acutus, situated laterally and ventrally forms the riglit and ventral borders.

The left border of the liver runs obliquely from dorsal side to ventral, cranial and median direction. The right border in the triangle-shaped liver runs dorsally and caudally, almost in parallel to ribs, hence it deviates laterally. In the livers showing other shapes this border runs from dorsal to ventral side, and simultaneously obliquely to cranial direction. The ventral border is separated from xiphoid cartilage of the sternum by 14 to $24 \mathrm{~cm}$, and in the triangle liver by as far as $33 \mathrm{~cm}$. 


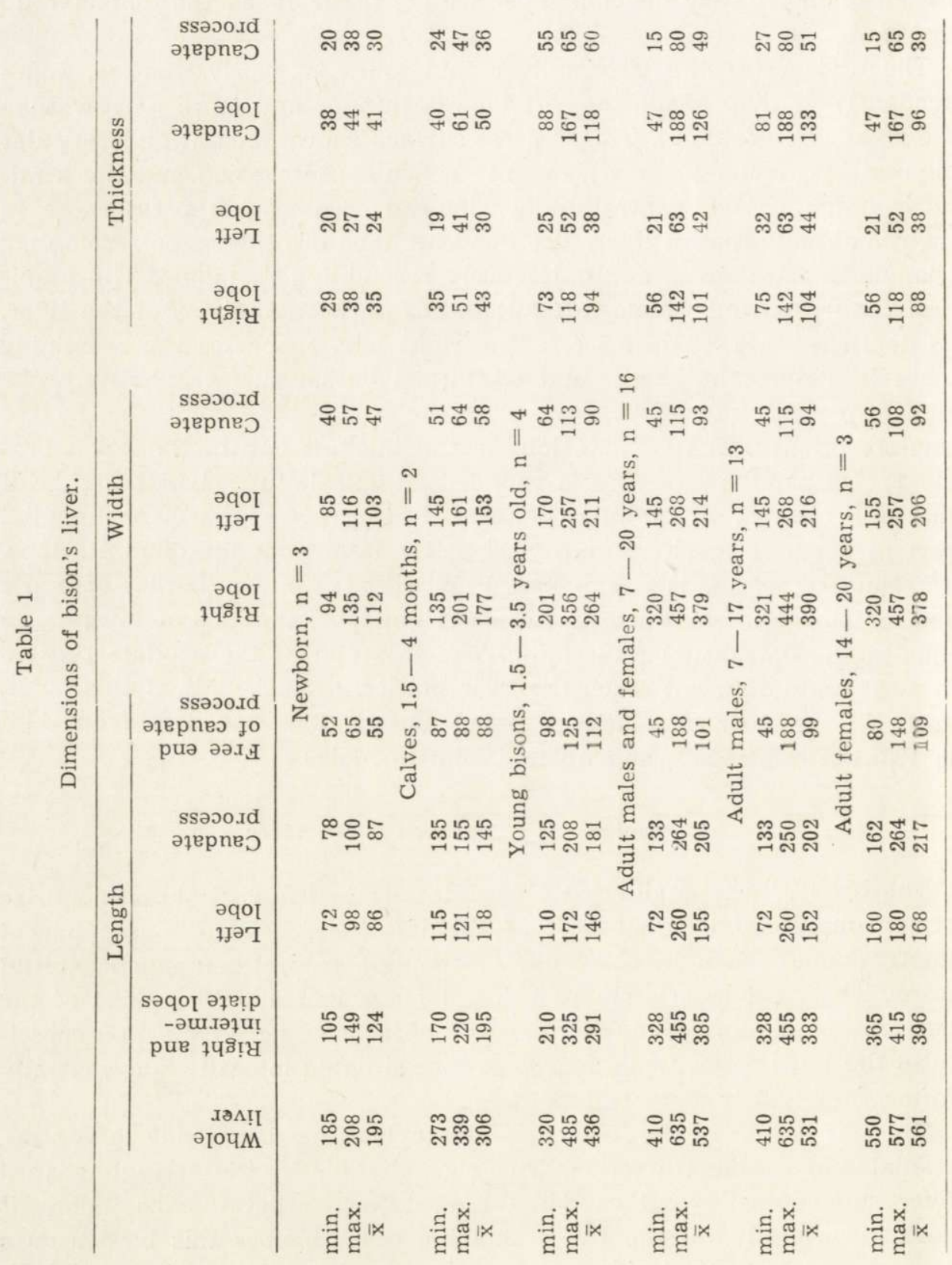


The liver of adult individuals lies between $7 \mathrm{rib}$ (or 7 intercostal space) and 13 intercostal space (14 rib). The cuadate process, when it protrudes beyond the liver border, is situated under the first lumbar vertebra. The right and intermediate hepatic lobes adjoin to ribs: directly to the last one, and through the diaphragm to ribs $13-10$. The gall bladder crosses margo acutus and in adult bisons lies at the level of 9 to 11 (12) ribs, in the fissure between omasum and abomasum. The gall bladder bottom is at the level of costochondrial junction.

The liver is fixed to the diaphragm, abdominal wall and neighbouring organs by means of numerous ligaments. The coronary ligament consist of two strong sheets of peritoneum and attaches liver to the diaphragm. Between the sheets there is a rather large area of diaphragmatic liver surface, to the right of posterior vena cava, devoid of peritoneum. The non-peritoneal area of the liver may be spindle-shaped, triangle or semilunar with the impression from the side of posterior vena cava. The right triangular ligament attaches the right lobe to the abdominal wall and diaphragm. On the abdominal wall it is fastened to 13 or 14 rib. The width of the ligament, measured at the liver, amounts to approximately $15 \mathrm{~cm}$. The left triangular ligament is poorly developed in the bison; it attaches the left lobe to the diaphragm below and slightly to the left of esophageal hiatus. The falciform ligament of the liver runs along the diaphragmatic surface, from posterior vena cava to umbilical fissure. Bisons older than 2 years are usually devoid of it (in one individual this ligament was preserved intact, and in three others - in rudimentary form). The hepatorenal ligament begins at the central segment of the medial border of caudate process and runs to the back, on the ventral surface of the right kidney. The hepatoomasal ligament begins at the visceral surface of the liver on the line: esophageal notch papillary process, and it runs to omasum elongating its serous membrane. The ligament is rather well developed and shows distinct borders near the liver. Lesser omentum is attached to the visceral surface, usually in the straight line between porta of the liver and esophageal notch, approximately $3 \mathrm{~cm}$ below the hepatoomasel ligament.

\section{Variability in the Shape, Size and Weight of the Liver Depending on Age}

In newborns and 6-week-old calves the liver resembles rectangle due to almost uniform development of the left and right lobes. On the visceral surface (mainly in left lobe) of these animals shallow fissures and impressions are found. The umbilical fissure is as a rule not visible from the visceral surface. The umbilical vein preserves patency in foetuses and 1-3-day-old individuals, later being transformed into the 
round ligament of the liver disappearing with age. The caudate process is relativelly large and, except one case, protrudes beyond the liver border.

The liver of young bisons (up to 3 years of age) is oval in shape, with the longer axis running from the dorsal border of the right lobe to ventral border of the left lobe. The latter one is smaller than the right lobe, especially in respect of thickness (Table 1). The umbilical fissure is 4 to $6 \mathrm{~cm}$ long and distinctly separates the left lobe from the intermediate lobe. On the visceral surface of the left lobe omasal impression appears, while in the vicinity of ventral border - reticular and abomasal impressions. The renal impression in the livers of this age group

Table 2

Body weight and absolute and relative weight of bison's liver.

\begin{tabular}{|c|c|c|c|c|c|}
\hline \multirow[b]{2}{*}{ Age group } & \multirow[b]{2}{*}{$\mathrm{n}$} & & \multirow[b]{2}{*}{ Body wt, kg } & \multicolumn{2}{|c|}{ Liver weight } \\
\hline & & & & $\begin{array}{c}\text { Absolute, } \\
\mathrm{g}\end{array}$ & $\underset{\%}{\text { Relative, }}$ \\
\hline Newborns & 4 & $\min _{\overline{\mathbf{x}}}$ & $\begin{array}{l}15.5 \\
35.0 \\
23.2\end{array}$ & $\begin{array}{l}370 \\
495 \\
448\end{array}$ & $\begin{array}{l}1.41 \\
2.39 \\
1.93\end{array}$ \\
\hline $\begin{array}{l}\text { Calves } \\
1.5-4 \text { months }\end{array}$ & 1 & & 71.0 & $\begin{array}{c}1345 \\
(N=2)\end{array}$ & 2.04 \\
\hline $\begin{array}{l}\text { Young bisons } \\
2-3.5 \text { years }\end{array}$ & 2 & $\min _{\overline{\mathrm{x}}}^{\min }$ & $\begin{array}{l}206.0 \\
408.0 \\
307.0\end{array}$ & $\begin{array}{l}4160 \\
4950 \\
4555\end{array}$ & $\begin{array}{l}1.21 \\
2.02 \\
1.67\end{array}$ \\
\hline $\begin{array}{l}\text { Adult males }+ \text { females } \\
6-20 \text { years }\end{array}$ & 7 & $\min _{\bar{x}}$ & $\begin{array}{l}530.0 \\
920.0 \\
698.8\end{array}$ & $\begin{array}{r}5350 \\
11000 \\
8210 \\
(\mathrm{~N}=12)\end{array}$ & $\begin{array}{l}1.05 \\
1.58 \\
1.17\end{array}$ \\
\hline Adult males $6-17$ years & 6 & $\min _{\overline{\mathbf{x}}}$ & $\begin{array}{l}530.0 \\
920.0 \\
727.0\end{array}$ & $\begin{array}{c}7000 \\
11000 \\
9011 \\
(\mathrm{~N}=9)\end{array}$ & $\begin{array}{l}1.05 \\
1.58 \\
1.24\end{array}$ \\
\hline Adult females $8.5-20$ years & 1 & & 530.0 & $\begin{array}{c}5803 \\
(\mathrm{~N}=3)\end{array}$ & 1.09 \\
\hline
\end{tabular}

is still rather shallow. The outline of intermediate lobe resembles a triangle based on porta of the liver with its apical part at the right border. The papillary process of the caudats lobe crosses over the range of porta of the liver. The caudate process of this lobe is prism-shaped with the three surfaces limited by three borders joining at the apical part of the process. One of these surfaces adjoins to the right lobe, other to the right kidney and posterior vena cava, and the last one - to duodenum.

In adult individuals the principal liver dimensions, length and width, are similar in both sexes (Table 1), while higher values of thickness were found in males, e.g. caudate lobe is thicker on the average by $37 \mathrm{~mm}$, right lobe - by $16 \mathrm{~mm}$. 
During the postnatal development the highest increase in size was observed for the right lobe, since its coefficients of growth amount to 3.4 (width) and 3.1 (thickness), as well as for the caudate lobe -3.1 in thickness. The lowest increase was observed for the caudate process, since its coefficient of growth is 1.6 (thickness), and for the left lobe thickness and length increased by 1.8 times.

The absolute weight of the liver of adult bisons is equal to $8210 \mathrm{~g}$ on the average (Table 2), in males being $36 \%$ higher than in females. In comparison with newborns this weight corresponds to over 18-fold increase. The relative weight of the liver amounts on the average to $1.17 \%$ (in adult females $1.24 \%$, in males $-1.09 \%$ ).

\section{Bile Passages}

The right hepatic duct turns toward the dorsal angle of the right lobe and is formed by the confluence of three strong branches: two for the

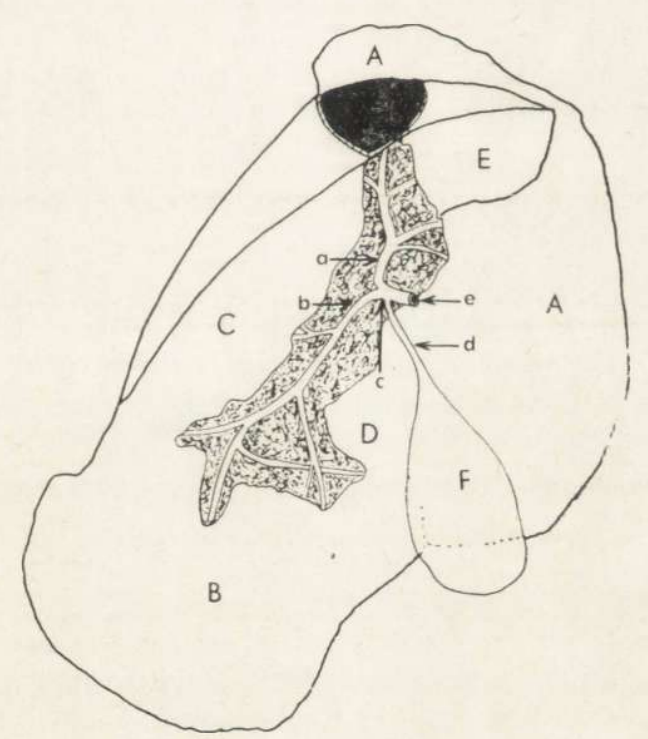

Fig. 4. Bile passages of bison's liver (scheme).

A - right lobe, B - left lobe, C - caudate lobe, D - quadrate lobe, E - caudate process, F - gall bladder, 1 - vena cava posterior, 2 - portal vein, a - right hepatic duct, b - left hepatic duct, c - common hepatic duct, d - cystic duct, $\mathrm{e}-$ bile duct.

dorsal part of the right lobe and one for the caudate process (Fig. 4). Two branches deriving from one third of the ventral and middle part 
of the right lobe join either separately or as one trunk to the terminal part of the described duct. The left hepatic duct lies in porta of the liver below portal vein. It crosses (on the diaphragmatic surface of the liver) the umbilical pouch and includes two initial branches. One of them spreads in the dorsal and middle part, and the second one - in the ventral part of the left lobe. The first one is supplied by a strong branch from the quadrate lobe, which in some cases may join directly to the left hepatic duct. The common hepatic duct, $2 \mathrm{~cm}$ long, is formed in porta of the liver by confluence of the right and left ducts. Variations: in one case the bile from the right lobe flowed by two separate ducts one from the dorsal part and caudate process, and the second - from the ventral and middle parts of this lobe.

Table 3

Dimensions $(\mathrm{mm})$ and capacity $\left(\mathrm{cm}^{3}\right)$ of the gall bladder in the bison.

\begin{tabular}{|c|c|c|c|c|c|}
\hline Age group & $\mathbf{N}$ & & Length & Width & Capacity \\
\hline \multirow{3}{*}{ Newborns } & \multirow[t]{3}{*}{4} & $\min$. & 30 & 9 & 4 \\
\hline & & $\max$. & 55 & 32 & 69 \\
\hline & & $\overline{\mathrm{x}}$ & 40 & 17 & 33 \\
\hline Calves & \multirow[t]{3}{*}{2} & $\min$. & 75 & 20 & 20 \\
\hline \multirow[t]{2}{*}{$1.5-4$ months } & & $\max _{\bar{x}}$ & 117 & 63 & 200 \\
\hline & & $\overline{\mathrm{x}}$ & 96 & 42 & 110 \\
\hline Young & \multirow[t]{3}{*}{4} & $\min$ & 121 & 45 & 78 \\
\hline \multirow[t]{2}{*}{$2-3.5$ years } & & $\max$. & 185 & 80 & 322 \\
\hline & & $\bar{x}$ & 153 & 56 & 213 \\
\hline Adult males + females & \multirow[t]{3}{*}{12} & $\min$ & 130 & 60 & 130 \\
\hline \multirow{2}{*}{$5-20$ years } & & $\max$. & 265 & 118 & 1650 \\
\hline & & $\overline{\mathrm{x}}$ & 203 & 94 & 756 \\
\hline \multirow{2}{*}{ Adult males $5-16$ years } & \multirow{2}{*}{10} & $\min$. & $\begin{array}{l}130 \\
233\end{array}$ & $\begin{array}{r}60 \\
118\end{array}$ & 130 \\
\hline & & $\overline{\mathrm{x}}$ & & $\begin{array}{r}118 \\
93\end{array}$ & $\begin{array}{r}1650 \\
694\end{array}$ \\
\hline \multirow[t]{3}{*}{ Adult females $14-20$ years } & \multirow[t]{3}{*}{2} & $\min$ & 228 & 72 & 500 \\
\hline & & $\max$. & 265 & 128 & 1630 \\
\hline & & $\overline{\mathrm{x}}$ & 246 & 100 & 1065 \\
\hline
\end{tabular}

Cystic duct in adult individuals is $7.5 \mathrm{~cm}$ long and is additionally supplied by 2 to 4 small ducts from the right and quadrate lobe. The bile duct formed near porta of the liver, between portal vein and papillary process, is 4.2 to $6 \mathrm{~cm}$ long and has $1.0-1.5 \mathrm{~cm}$ in diameter.

The gall bladder of the bison is well developed and hangs below the right liver border. In adult individuals it reaches $20 \mathrm{~cm}$ of length and $750 \mathrm{~cm}^{3}$ in volume (Table 3). The gall bladder is attached to the visceral surface of the liver usually in the line between portal vein and umbilical fissure. One or two small ducts from the right and quadrate lobe reach directly to the gall bladder. 


\section{DISCUSSION}

In general outline the bison's liver is similar to cattle liver, but differs in some morphological details resembling the conditions described in other ruminants, especially in buffalo (M a r tiros jan, 1953).

The liver of adult bisons is variable in shape, triangular in most cases, while in cattle, especially in older and undernourished individuals, the elongated form prevails (E i c h el, 1925). In comparison with cattle the left lobe of bison's liver is less developed but in a variable degree, due to the pressure exerted by reticulum and mainly by omasum. It has been found (after comparison of the results of stomach capacity with observations on the shape of the liver in the same individuals P y te l, 1969), that triangular liver is accompanied by a larger capacity of the omasum than in case of the liver with fully developed left lobe. It appears, moreover, that poorly developed left lobe has no relationship to the displacement of organs in the peritoneal cavity during pregnancy since it occurs with equal frequency in females and males. This is understandable since the reticulum and omasum, in distinction to abomasum, are only slightly displaced during pregnancy (H á jov ská, 1964). The fact that triangular liver was not observed in the animals under 4 years of age should be related to the postnatal development of omasum ( $\mathrm{Py}$ te 1,1969$)$. The process of reduction of the left lobe associated with age was also described in the camel ( $\mathrm{Z}$ e d e nov, 1965). The caudate lobe and its papillary process are better developed in the bison than in cattle (Eichel, 1925). In bison calves the papilary process is shaped similarly to that in cattle calves (Geyer et al., 1971) and in adult sheep ( $\mathrm{Kl}$ a g e s, 1931). The caudate process in adult bisons, is prismshaped while in cattle is flattened, of rounded borders and broad apex, and often may be quadrate (A u e rnheimer, 1910; E i chel, 1925). The shape of this process in the bison resembles that described in buffalo (Martirosjan, 1963). The quadrate lobe in the bison liver is most often triangular, while in cattle conforms with its name. The umbilical fissure is deeper in bison than in cattle. The line of attachment of the gall bladder is closer to the umbilical fissure in bison's liver than in cattle (Martin \& Schauder, 1938; Ellenberger-Baum, 1943; Sisson \& Grossman, 1960) and resembles conditions described in sheep and goat (Nickel, Schummer \& Seiferle, 1960). The bison liver has also deeper renal impression.

The dimensions of the liver in newborn bisons are similar to the corresponding data for cattle (G e yer et al., 1971; Eichel, 1925). In the individuals aged 1.5 to 3.5 years the mean length of the left lobe in the bison corresponds to the lowest values in cattle, and of the right 
and intermedial lobes - to the highest values. The width of the left lobe in this age group is identical with that in cattle. In adult bisons the length of the whole liver does not differ from that of the cattle

Table 4

Comparison of the mean dimensions $(\mathrm{mm})$ of bison and cattle liver.

\begin{tabular}{|c|c|c|c|c|}
\hline & \multicolumn{2}{|c|}{ Bulls } & \multicolumn{2}{|c|}{ Cows } \\
\hline & Bisons & Cattle $^{1}$ & Bisons & Cattle $^{1}$ \\
\hline \multicolumn{5}{|l|}{ Length } \\
\hline Whole liver & 531 & 533 & 561 & 557 \\
\hline Right and intermediate lobes & 383 & 300 & 396 & 307 \\
\hline Left lobe & 152 & 233 & 168 & 250 \\
\hline Caudate process & 202 & 162 & 217 & 156 \\
\hline Free end of caudate process & 99 & 100 & 109 & 102 \\
\hline \multicolumn{5}{|l|}{ Width } \\
\hline Right lobe & 390 & 310 & 378 & 329 \\
\hline Left lobe & 216 & 268 & 206 & 270 \\
\hline Caudate process & 94 & 100 & 92 & 102 \\
\hline \multicolumn{5}{|l|}{ Thickness } \\
\hline Right lobe & 104 & 90 & 88 & 84 \\
\hline Left lobe & 44 & 37 & 38 & 37 \\
\hline
\end{tabular}

1 After Eichel (1925)

Table 5

Comparison of liver weight of the bison, cattle and their $F_{1}$ hybrids.

\begin{tabular}{|c|c|c|c|c|c|c|c|}
\hline \multirow{2}{*}{ Species } & \multicolumn{3}{|c|}{ Absolute weight $(\mathrm{g})$} & \multicolumn{3}{|c|}{ Relative weight $\left(\begin{array}{l}q \\
o\end{array}\right)$} & \multirow{2}{*}{ Authority } \\
\hline & mean & $\min$. & $\max$. & mean & $\min$. & $\max$ & \\
\hline \multicolumn{8}{|c|}{ Males } \\
\hline Bisons & 9011 & 7000 & 11000 & 1.24 & 1.05 & 1.58 & Our own data \\
\hline Cattle & 6200 & 4250 & 8525 & 1.04 & & & Eichel, 1925 \\
\hline Cattle & 5947 & 3100 & 8450 & 1.02 & 0.81 & 1.18 & Schneider, 1904 \\
\hline Cattle-Oxen & 7607 & 4995 & 11540 & 1.04 & & & Schneider, 1904 \\
\hline$F_{1}$ hybrids & 11860 & & & 1.28 & & & Pilarski \& \\
\hline & \multicolumn{7}{|c|}{ Females } \\
\hline Bisons & 5803 & 5350 & 6100 & 1.09 & & & \\
\hline Cattle & 6070 & 3450 & 9200 & 1.10 & & & Eichel, 1925 \\
\hline Cattle & 5497 & 3700 & 7800 & 1.21 & 0.94 & 1.46 & Schneider, 1904 \\
\hline Cattle $^{1}$ & 7110 & & & 1.71 & & & Kwiatkowski, 1973 \\
\hline Cattle $^{2}$ & 5710 & & & 1.55 & & & Kwiatkowski, 1973 \\
\hline$F_{1}$ hybrids & 7353 & & & 1.43 & & & Pilarski \& \\
\hline & & & & & & & Krasińska, 1976 \\
\hline
\end{tabular}

${ }_{1}$ Polish Red, ${ }^{2}$ Jersey

('Table 4). The length of the right and intermediate lobes is in bison higher by $83 \mathrm{~mm}$ on the average, and of the left lobe (independently of the degree of its development) is lower by $81 \mathrm{~mm}$ than in cattle. The length of the free end of caudate process is equal to that in the cattle. The width of the left lobe is in bison $51 \mathrm{~mm}$ lower than in cattle. In respect of thickness the right lobe of bison liver exceeds by $14 \mathrm{~mm}$, 
and left lobe by $7 \mathrm{~mm}$, the corresponding dimensions of cattle liver.

The absolute weight of one-day-old bisons is lower than that of cattle (No skov, 1963; Eichel, 1925; Blin et al., 1963). In adult bison males the liver is heavier by ca $3 \mathrm{~kg}$ than in bulls and by $1.5 \mathrm{~kg}$ than in oxen (Table 5). Such significant weight differences accompanying small differences of liver dimensions of the compared animals may arise from a variable degree of exsanguination of cattle killed in the slaughter house in distinction to bisons that were either dead in natural way or put asleep. It may also be related to different body weight of compared species, since in newborns the relative weight of the liver is lower in bison than in cattle (E ichel, 1925, Tamate et al., 1962, Blin et al., 1963). As far as adult individuals are concerned the relative weight of the liver is in bison either lower (females) or higer (males) than in cattle. It should be mentioned, however, that the material used for comparison may be not sufficient. The liver of adult $F_{1}$ hybrids of bison and cattle is heavier in both sexes than bison's liver, both in absolute and relative terms (P i larski \& Krasińs k a, 1976).

\section{REFERENCES}

1. A u e rnheimer O., 1910: Grossen- und Formveränderungen der Baucheingeweide der Wiederkäuer nach Geburt bis zum erwachsenen Zustand. Z. Fleisch- u. Milchhyg., 20: 393-396.

2. B evandić M., Arnautović I., Krčmar I. \& Lorger I., 1967: Komparativni preglad żucovodnih puteva domačih żivotinja. Veterinaria, 3: $301-315$.

3. Blin P. C., Bossavy A. \& Fournier Cl., 1963: Dynamique pondèrale et linèaire des estomacs, du fois et de l'intestin des foetus bovin et ovin. Econom. et Mèd. Animal., 4, 3: 141-160.

4. Eichel J., 1925: Masse, Formen und Gewichte der Lebern von Rindern und Schafen. Diss. Berlin.

5. Ellenberger-Ba um, 1943: Handbuch der vergleichenden Anatomie der Haustiere. Springer Verl.; 449-451, Berlin.

6. Geyer H., Aberger G. \& Wissdorf H., 1971: Beitrag zur Anatomie der Leber beim neugeborenen Kalb. Schweiz. Archiv f. Tierheilk., 13, 10: $577-586$.

7. Há jovská B., 1965: Zmeny v topografii predžalúdkov a slezu u oviec počas gravidity. Folia Vet., 9: 147-156.

8. Klages C., 1931: Anatomische Untersuchungen des Gefässverlaufs der Leber neugebornen Schafe und Geburtsreifer Rinder. Morph. Jh., 68: 301-324.

9. K wiatkowski J., 1973: Próba oceny i porównania wartości rzeźnej krów rasy czerwonej polskiej, jersey i mieszańców $F_{1}$ tych ras. Prace i Mat. Zootech., 3: 7-22.

10. Martin P. \& Schauder W., 1936: Lehrbuch der Anatomie der Haustiere. Schickhart u. Ebner, 3: 207-238, Stuttgart.

11. Martirosjan A., 1953: Morfologičeskie osobennosti glavnyh piščevaritelnyh želez bujvola. Tr. Erev. Zoovet. Inst., 15: 135-141. 
12. M üller F., 1852: Bemerkungen über den Auerochsen. Vierteljahrschr. Wiss. Wet. Kunde, 2: 110-133. Berlin.

13. Nickel R., Schummer A. \& Seifer le S., 1960: Lehrbuch der Anatomie der Haustiere. P. Parey, 2: 177-181. Berlin und Hamburg.

14. Noskov I., 1963: Morfologičeskie osobennosti nekotoryh organov u novoroždennyh telat krasnoj stepnoj porody skota. Mat. nauč.-metod. konf. Anat. Gistol. Embriol., 1: 155-156.

15. Owen F., 1848: Notes on the anatomy of the male aurochses (Bison europeus L.). Proc. zool. Soc., London, 16: 126-133.

16. Pilarski W., Serwatka S., Swiézyński K. \& Węgrzn M., 1967: New attempts at fixing anatomical material of large mammals. Acta theriol., 12, 31: $453-458$.

17. Pilarski W. \& Krasińska M., 1976: Analiza morfologiczna niektórych narządów wewnętrznych hybrydów żubra z bydłem domowym. Acta theriol., 21 (in print).

17. Pytel S., 1969: Morphology of digestive tract of the European bison. Acta theriol., 14, 27: 349-402.

19. Schneider J., 1904: Das absolute und relative Gewicht des Hertzens, der Lunge, der Leber, der Niere und der Milz von Rind. Z. Fleisch- u. Milchhyg., 14: $393-398$.

20. Sisson S. \& Grossman J., 1960: The anatomy of the domestic animals. W. B. Saunders Co., 1: 472-475. Philadelphia, London.

21. Sztolcman J., 1926: Żubr, jego historia, obyczaje i przyszłość. Nakł. Centr. Zw: Pol. Stow. Łow.: 1-104. Warszawa.

22. T a mate H., Mc Gilla rd A. D., Jacobson N. L. \& Getty R., 1962: Effect of various dietaries on the anatomical development of the stomach in the calf. J. Dairy Sci., 45: 408-420.

23. Z $\angle$ a rzy cki J., 1957: O budowie histologicznej niektórych narządów wewnętrznych żubra, Bison bonasus L., Zool. pol., 8: 53-62.

24. Ž e denov V., 1965: Anatomia domašnih životnyh. Izdat. Vys. Škola, 2: 151166. Moskva.

Accepted, January 21, 1975.

Stanisław PYTEL i Mieczysław WĘGRZYN

\section{MORFOLOGIA WĄTROBY ŻUBRA}

Badania przeprowadzono na wątrobach 47 żubrów (32 $\sigma^{x} \sigma^{x} \mathrm{i} 15$ 웅) w wieku od 1 dnia do 24 lat. Na materiale utrwalonym wykonano obserwacje morfologiczne i pomiary; dane odrośnie ciężaru dotyczą materiału świeżego.

Wątroba żubra podobna jest do wątroby bydła domowego. Ma ona barwę brunatno-czerwoną, miernie wyrażoną budowę zrazikową oraz niewyraźny podział na płaty: prawy, lewy, czworoboczny i ogoniasty. W zależności od stopnia rozwoju poszczególnych płatów (głównie lewego) wątroba u żubrów dorosłych może mieć kształt trójkątny ( $56 \%$ przypadków), prostokątny $(12 \%)$ lub między nimi pośredni $(32 \%$ - Rys. $1-3)$.

Wątroba żubra, w porównaniu z wątrobą bydła domowego, charakteryzuje się silniejszym płatem prawym i słabszym płatem lewym (Tabela 1 i 4). Ciężar bezwzględny wątroby dorosłych żubrów wynosi $8,21 \mathrm{~kg}$ (u samców $-9,01 \mathrm{~kg}$, u samic $-5,80 \mathrm{~kg}$ ) natomiast ciężar względny $-1,17 \%$ (odpowiednio $-1,24 \%$ i $1,09 \%$ ). W odniesieniu do wątroby bydła domowego, wątroba dorosłych żubrów - samców jest cięższa od wątroby buhajów i wołów (Tabela 5). 